\title{
Short term effects of levonorgestrel-releasing intrauterine systems: a systematic review with meta-analysis
}

\author{
Emma Illum ${ }^{1}$, Hanne Wolf ${ }^{2}$, and Jeppe Schroll ${ }^{2}$ \\ ${ }^{1}$ Affiliation not available \\ ${ }^{2}$ Hvidovre Hospital
}

October 20, 2020

\begin{abstract}
Background: The levonorgestrel intrauterine systems (LNG-IUS) is widely used, but few studies report incidence rates of side-effects of LNG-IUS. Objectives: The purpose of this study was to investigate short term side effects of LNG-IUS and to compare the side effects at different dosages of LNG-IUS's. Search strategy: We searched electronic databases (MEDLINE, Embase, Cochrane) for RCT's and observational studies between January 1970 and April 2019 published in English. Selection criteria: Studies including women seeking contraception and receiving a LNG-IUS, compared to either women without hormonal contraception or a different dosage of a LNG-IUS. Data Collection and analysis: We evaluated randomized controlled trials with the Cochrane Risk of Bias tool and observational studies with ROBINS-I. For outcomes with data from at least two studies, meta-analysis was conducted using RevMan (version 5.3). The quality of evidence was assessed using the GRADE. Main results: We found an increase in risk of nervousness, depression, ovarian cysts and of amenorrhea. One study compared two different LNG-IUSs and found a decreased risk of developing ovarian cysts and an uncertain risk of ectopic pregnancies and mood swings in low dose LNG-IUS. Conclusions: We found that LNG-IUS increases risk of nervousness, depression, ovarian cysts and amenorrhea but the quality of evidence was low and the absolute risk small. Low-dosage LNG-IUS decreases the risk of ovarian cysts compared to high dose. To achieve higher quality of evidence, further studies are needed. Funding: No funding was received for this study. Keywords: LNG-IUS, LNG-IUD, side-effects, ovarian cysts, amenorrhea, depression, ectopic pregnancies
\end{abstract}

\section{Hosted file}

Short term effects of LNG-IUS.pdf available at https://authorea.com/users/368737/articles/ 487777-short-term-effects-of-levonorgestrel-releasing-intrauterine-systems-a-systematicreview-with-meta-analysis

\section{Hosted file}

Figure 1.pdf available at https://authorea.com/users/368737/articles/487777-short-termeffects-of-levonorgestrel-releasing-intrauterine-systems-a-systematic-review-with-metaanalysis

\section{Hosted file}

Figure 2a.pdf available at https://authorea.com/users/368737/articles/487777-short-termeffects-of-levonorgestrel-releasing-intrauterine-systems-a-systematic-review-with-metaanalysis

\section{Hosted file}


Figure 2b.pdf available at https://authorea.com/users/368737/articles/487777-short-termeffects-of-levonorgestrel-releasing-intrauterine-systems-a-systematic-review-with-metaanalysis

\section{Hosted file}

Figure 3a.pdf available at https://authorea.com/users/368737/articles/487777-short-termeffects-of-levonorgestrel-releasing-intrauterine-systems-a-systematic-review-with-metaanalysis

\section{Hosted file}

Figure 3b.pdf available at https://authorea.com/users/368737/articles/487777-short-termeffects-of-levonorgestrel-releasing-intrauterine-systems-a-systematic-review-with-metaanalysis

\section{Hosted file}

Figure 4.pdf available at https://authorea.com/users/368737/articles/487777-short-termeffects-of-levonorgestrel-releasing-intrauterine-systems-a-systematic-review-with-metaanalysis

\section{Hosted file}

Figure 5.pdf available at https://authorea.com/users/368737/articles/487777-short-termeffects-of-levonorgestrel-releasing-intrauterine-systems-a-systematic-review-with-metaanalysis

\section{Hosted file}

Figure 6.pdf available at https://authorea.com/users/368737/articles/487777-short-termeffects-of-levonorgestrel-releasing-intrauterine-systems-a-systematic-review-with-metaanalysis

\section{Hosted file}

Figure 7a.pdf available at https://authorea.com/users/368737/articles/487777-short-termeffects-of-levonorgestrel-releasing-intrauterine-systems-a-systematic-review-with-metaanalysis

\section{Hosted file}

Figure 7b.pdf available at https://authorea.com/users/368737/articles/487777-short-termeffects-of-levonorgestrel-releasing-intrauterine-systems-a-systematic-review-with-metaanalysis

\section{Hosted file}

Figure 8a.pdf available at https://authorea.com/users/368737/articles/487777-short-termeffects-of-levonorgestrel-releasing-intrauterine-systems-a-systematic-review-with-metaanalysis

\section{Hosted file}

Figure 8b.pdf available at https://authorea.com/users/368737/articles/487777-short-termeffects-of-levonorgestrel-releasing-intrauterine-systems-a-systematic-review-with-metaanalysis

\section{Hosted file}


Figure 9a.pdf available at https://authorea.com/users/368737/articles/487777-short-termeffects-of-levonorgestrel-releasing-intrauterine-systems-a-systematic-review-with-metaanalysis

\section{Hosted file}

Figure 9b.pdf available at https://authorea.com/users/368737/articles/487777-short-termeffects-of-levonorgestrel-releasing-intrauterine-systems-a-systematic-review-with-metaanalysis

\section{Hosted file}

Figure 10.pdf available at https://authorea.com/users/368737/articles/487777-short-termeffects-of-levonorgestrel-releasing-intrauterine-systems-a-systematic-review-with-metaanalysis

\section{Hosted file}

Figure 11.pdf available at https://authorea.com/users/368737/articles/487777-short-termeffects-of-levonorgestrel-releasing-intrauterine-systems-a-systematic-review-with-metaanalysis 